\title{
Social representations of agressive men denounced for violence against women
}

\author{
Representações sociais de homens agressores denunciados acerca da violência contra a mulher
}

Representaciones sociales de hombres agresores denunciados acerca de la violencia contra la mujer

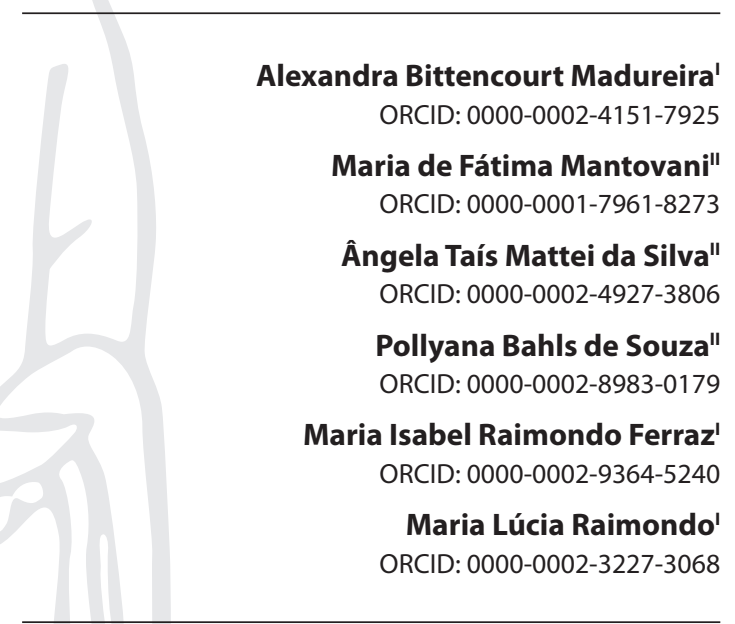

'Universidade Estadual do Centro-Oeste. Guarapuava, Paraná, Brazil.

"Universidade Federal do Paraná. Curitiba,Paraná, Brazil.

How to cite this article:

Madureira AB, Mantovani MF, Silva ATM, Souza PB,

Ferraz MIR, Raimondo ML. Social representations of agressive men denounced for violence against women.

Rev Bras Enferm. 2020;73(2):e20180824

doi: http://dx.doi.org/10.1590/0034-7167-2018-0824

Corresponding Author:

Ângela Taís Mattei da Silva

E-mail: angelataismattei@gmail.com

EDITOR IN CHIEF: Antonio José de Almeida Filho ASSOCIATE EDITOR: Hugo Fernandes

Submission: $10-22-2018$

Approval: 02-13-2019

\begin{abstract}
Objectives: To acknowledge the social representations of aggressive men denounced for violence against women. Methods: A qualitative study based on the Theory of Social Representations, carried out with 12 men denounced for violence against women. Data were collected from February 2015 to April 2016, through an interview focused on the Special Women's Police Station (Delegacia Especial da Mulher) in of Guarapuava. The analysis was based on the transcription, coding and use of the software Interface de $R$ pour les Analyses Multidimensionnelles de Textes et de Questionnaire. Results: Four categories were defined: from generation to generation: the spread of violence; feelings and behaviors in the face of violence; repercussions of violence on the aggressor; and, the aggressor and his victimization. Final considerations: Men represent conjugal violence through victimizing and blaming women. The living of these men with violence comes from their childhood and the consequence feared by them is the prison.

Descriptors: Violence against Women; Violence by Intimate Partner; Nursing; Gender Violence; Family Conflict.
\end{abstract}

\section{RESUMO}

Objetivos: Conhecer as representações sociais de homens denunciados por agressão acerca da violência contra a mulher. Métodos: Estudo qualitativo alicerçado na Teoria das Representações Sociais, realizado com 12 homens denunciados por violência contra a mulher. Os dados foram coletados de fevereiro de 2015 a abril 2016, por meio de entrevista focalizada na Delegacia Especial da Mulher de Guarapuava. A análise se deu a partir da transcrição, codificação e utilização do software Interface de $R$ pour les Analyses Multidimensionnelles de Textes et de Questionnaire. Resultados: Estabeleceram-se quatro classes: de geração à geração: o propagar da violência; sentimentos e comportamentos diante da violência; repercussões da violência para o agressor; e, o agressor e a sua vitimização. Considerações finais: Os homens representam a violência conjugal mediante a vitimização e culpabilização da mulher. $\mathrm{O}$ convívio desses homens com a violência vem desde sua infância e a consequência temida por eles é a prisão.

Descritores: Violência contra a Mulher; Violência por Parceiro Íntimo; Enfermagem; Violência de Gênero; Conflito Familiar.

\section{RESUMEN}

Objetivos: Conocer las representaciones sociales de hombres agresores denunciados acerca de la violencia contra la mujer. Métodos: Estudio cualitativo basado en la Teoría de las Representaciones Sociales, realizado con 12 hombres denunciados por violencia contra la mujer. Los datos fueron recolectados de febrero de 2015 a abril de 2016, por medio entrevista enfocada en la Comisaría Especial de la Mujer de Guarapuava. El análisis ocurrió a partir de la transcripción, codificación y utilización del software Interface de $R$ pour les Analyses Multidimensionnelles de Textes et de Questionnaire. Resultados: Fueron establecidas cuatro clases: de generación a generación: el propagar de la violencia; sentimientos y comportamientos ante la violencia; repercusiones de la violencia para el agresor; y el agresor y su victimización. Consideraciones finales: Los hombres representan la violencia conyugal mediante la victimización y la culpabilización de la mujer. La convivencia de estos hombres con la violencia viene desde su infancia y la consecuencia temida por ellos es la prisión. Descriptores: Violencia contra la Mujer; Violencia por Compañero Íntimo; Enfermería; Violencia de Género; Conflicto Familiar. 


\section{INTRODUCTION}

Gender violence is a phenomenon of epidemic proportions and it permeates the lives of the female population worldwide. It starts, mainly, due to unresolved conflicts at home, thus confirming the gender inequality perpetuated in societies.

Violence violates human rights, limits women's participation in society, causes great suffering and a negative impact on the lives, not only of the victims, but of the whole family living in this context $^{(1)}$. Therefore, it is recognized as a public health problem with great social and family impacts ${ }^{(2)}$.

A global estimate of the prevalence of violence, based on data from 79 countries worldwide by the World Health Organization, showed that $35 \%$ of women over 15 had already experienced physical and/or sexual violence. The percentage is even higher in Africa, Southwest Asia and the Middle East, where approximately $37 \%$ of women reported experiencing lifelong violence. Intimate partners were the perpetrators in $30 \%$ of the cases $^{(1)}$.

Regarding mortality rates, Brazil ranks $5^{\text {th }}$ in the world ranking of female homicides victims, with a rate of 4.8 deaths per 100,000 women. From 2006 and 2013, there was an 18.4\% increase in the number of women killed as a result of violence ${ }^{(3)}$. A global study also showed that intimate partners are also responsible for $38 \%$ of all homicides of women committed in the world ${ }^{(1)}$.

Faced with the complexity and aggravation of the women's health-disease process, violence needs to be analyzed as a complex adversity, of multifactorial causes and outcomes that go beyond physical damage. Thus, it requires from health professionals actions that surpass their identification and referrals to other departments of a coping network ${ }^{(4)}$.

The regularity presented by the cases of violence practiced against Brazilian women can be understood as a chronic health problem, given it increases the demand of this population for care in health services and raises the rates of feminicide ${ }^{(5)}$. Thus, due to the impact of violence against women and its chronic character, there is a need to strengthen care lines and other types of actions to prevent this event from ocurring ${ }^{(6)}$.

Global epidemiological data indicate that violence against women occurs domestically, and its main perpetrators are the men with whom they maintain or maintained an intimate affective relationship ${ }^{(1)}$. In this context, innumerable factors impact on the woman's decision of not wanting to end the relationship and to remain in the context where she can be subjected to repeated episodes of violence during her life. On the other hand, when the relationship is over, the aggressor tends to establish new affective bonds, and in the face of everyday conflicts, violent behavior may resurface and affect other women ${ }^{(7)}$.

In addition to providing victim care services, more efforts are needed to prevent violence from happening. The need to address sociocultural factors that foster a culture of violence against women, such as social factors that reiterate male control and power over women, and the reduction of gender inequalities ${ }^{(1)}$ is highlighted. It is imperative to broaden the view on the phenomenon of violence, to include men who are the perpetrators of violence in discussions, research, policies and actions to prevent and combat violence.

Over the last years, different studies were carried out to understand domestic violence against women. However, although the approach of victims is an important source of information, the relevance of developing studies with men who practice violence is relevant to obtain further information about the phenomenon.

Men who are authors of violence elaborate representations, based on their experiences and that can be apprehended with studies. Knowing the social representations of men who are authors of violence against women can subsidize the elaboration of public policies aimed at changing violent behaviors adopted by men for the resolution of domestic conflicts.

The Theory of Social Representations is a possibility to respond to what is questioned, since it seeks to understand how the subjects think, feel and act, considering that they are elements of a social fabric in which there are constant symbolic and affective exchanges to apprehend the spaces, objects, discourses, the other and the reality that is materialized in their lives ${ }^{(8)}$.

Studies focusing on the social representations of men perpetrators of violence are an important instrument for the practice of health professionals, once they can provide subsidies for care planning. The individual or social representations show that "at any moment, something absent adds to it and something present changes, but the play of this dialectic has a greater meaning"(9).

This understanding led to the following question: what are the social representations of men denounced for violence against women?

\section{OBJECTIVES}

To acknowledge the social representations of aggressive men denounced for violence against women.

\section{METHODS}

\section{Ethical aspects}

Research complied with the ethical and legal requirements defined by Resolution 466/2012 of the National Health Council and was approved by the Ethics Committee on Research with Human Beings of the Universidade Estadual do Centro-Oeste (State University of the Center-West) (UNICENTRO).

Initially, the participants were invited to be part of research and knew the method by which they would be approached and who would interview them. The anonymity of participants, in the assessment and exposure of results, was preserved by hiding the names, which were replaced by "Ind" (Individual), followed by the Arabic numerals corresponding to the interview order.

\section{Type of study}

This is a qualitative study based on the Theory of Social Representations ${ }^{(9)}$, organized according to the Consolidated criteria for reporting qualitative research (COREQ) ${ }^{(10)}$.

The choice for the Theory of Social Representations as a theoretical-methodological referential was made because it allows to give voice to the participants of research and capture the interpretation of a common reality in a given social group ${ }^{(9)}$.

Social representation is a private knowledge that permeates social relations and aims to elaborate the attitudes and dialogues between the subjects. It allows to give meaning to conducts, 
to add it to a network of relations, providing the knowledge, theories and observations and enabling the relationships to be plausible and effective ${ }^{(9)}$.

\section{Methodological procedures}

\section{Research setting}

The research development site was the Special Women's Special Police Station in the city of Guarapuava, central region of Paraná State. According to the Map of Violence from 2015, the region ranked $373^{\text {th }}$ in the number of feminicides, with an average rate of 6.5 out of 5,565 municipalities with more than 10,000 women. This rate is high above the national average $(4.8 / 100,000)$ and that of Paraná $(5.2 / 100,000)$ for the same period ${ }^{(3)}$.

\section{Data sources}

The participants in research were 12 men reported for practicing violence against women, who met the following inclusion criteria: they were between 18 and 59 years old, summoned to testify because of a report of violence against their partner or expartner, able to express themselves verbally about their lives. The criterion of exclusion was that they were denounced for other types of violence. The number of participants in research was established by theoretical saturation, through analysis and continuous discussion of data among the researchers.

The selection regarding their age is justified in the light of a study carried out at the police station, in which the main age group among men in flagrante delicto for practicing violence against women was that of young adults, 20 to 29 years old $(45.4 \%)$, followed by those aged $40-49(22.3 \%)^{(7)}$.

\section{Data collection and organization}

Data collection was performed by the first author, between 2015 and 2016, at the Special Women's Police Station, in a private space provided by the institution or at another place of choice of participants, in order to provide comfort and freedom to express themselves.

To obtain the data, a focused interview was used. Field notes were taken during and after the interviews. The question that prompted them was: talk about your life since childhood, describe your relationships with relatives, friends and parents and the aspects that marked you until today, with emphasis on family relationships.

Using the focused interview, as a technique of data collection in qualitative research, allows researchers to deepen the conversation on a defined theme, without needing to establish a previously structured script ${ }^{(11)}$.

The interviews lasted approximately 26 minutes, were recorded in audio and transcribed in full into a text document. Subsequently, they were coded according to the recommended by the software used in research, composing a body for analysis. No interviews had to be repeated.

In order to improve the research strategies and procedures, prior to starting valid data collection for this study, a pilot test was carried out considering the same location and the inclusion criteria of participants.

\section{Data analysis}

For data analysis, the interviews were transcribed, coded and analyzed by the software Interface de $R$ pour les Analyses Multidimensionnelles de Textes et de Questionnaire (Iramutec) and, to present the results, the Descending Hierarchical Classification was used and defined four categories: 1) From generation to generation: the spread of violence; 2 ) Feelings and behaviors in the face of violence; 3 ) Repercussions of violence for the aggressor; and 4) The aggressor and his victimization.

\section{RESULTS}

Regarding the variable age, $58.3 \%$ of the participants were young adults, with emphasis on the age group from 20 to 40 years old; $83.3 \%$ had one to three children with the complainant; $50 \%$ declared themselves married and $33.3 \%$ were single. Regarding the time of contact with the complainant, the period of two to six years stands out, cited by $41.7 \%$ of the participants; $41.7 \%$ lived together for more than 12 years. As for the variable existence of a couple's child, $87.3 \%$ had children with the accused.

The types of violence, for which each participant was accused, were: moral violence, mentioned by $41.7 \%$ of the participants; and physical/moral and psychological, both cited by $17.7 \%$ of the men. Concerning the existence of previous complaints, $75 \%$ of the participants reported that they had not previously been accused of violence against their partners.

Processing the corpus by the software Iramutec generated 1,053 text segments, of which $86.1 \%$ (907) were used. Then, the software performed the partitions of the corpus, creating two subcorpus. The first contains classes 1 and 2, composed of 252 (27.78\%) Elementary Context Units (UCEs) and 269 UCEs (29.66\%) of the total corpus, respectively. The second subcorpus originated classes 3 and 4, with 119 (13.12\%) UCEs and 267 UCEs (29.44\%) of the total corpus, respectively.

The categories were listed and renamed so that they would be presented according to the chronological order of events: 1) From generation to generation: the spread of violence; 2 ) Feelings and behaviors in the face of violence; 3 ) Repercussions of violence for the aggressor; and 4) The aggressor and his victimization.

In Category 1) From generation to generation: the spread of violence, the family relations of participants are represented since childhood until the present day. This emphasizes the presence and practice of violence by parents or responsible people for resolving family conflicts and spreads of the model in the current relations of participants, which can be seen in the following statements:

[...] the relationship my parents had was terrible [...] my father would beat my mom really hard [...] both physical and verbal violence occurred. (Ind. 03)

He was a bad person. My father would beat my stepmother, [...] he was a really bad person. (Ind. 09)

Violence is the foundation of the family relations of the participants. In addition to witnessing the violence suffered by their mother during childhood, they were also submitted to it. Today, participants are those who practice it to educate their children, which can be evidenced in the following statements: 
My mom would always beat me when I was a child; my dad also did it, but I never beat my children, I only talk to them. (Ind. 7)

Today, I beat my 17-year-old daughter, to teach her a lesson, it was the only time. I think I never beat my son, maybe I smacked him a few times. (Ind. 12)

Here are the excerpts from the testimonies of men regarding their relations with their current or former partners, highlighting their representations of the conflicts and their resolution.

[...] I lived with my first wife for ten years and we never had any kind of problems [...] there was never any conflict, because my first wife never worked [...] she would stay at home, fulfilled her responsibilities and I did mine. [...] I don't even remember what started the fight, I just know it was ten or twelve years ago [...] it was a silly discussion [...] we always figured it out, we got along with each other. [...] for all the time we lived together. [...] (Ind. 01)

[...] I felt a sudden rage, it was something I didn't remember it happened to me when I was a child, it just controlled me. I dated her for almost 5 years, we had a good relationship, [...] there was a heated argument once, at the beginning [...] / went to her grandma's house and her whole family was there, [...] / threw away everything she had given me, [...] that was in our third year together. (Ind. 11)

In category 2) Feelings and behaviors in front of the violence, the social representations bring the position before the conflicts that appear in the relations and affirm that the main form to avoid them is with dialogue. However, when conflicts arise, feelings such as jealousy, ingratitude, sadness and revenge serve to justify and/or legitimate the reaction to these situations.

[...] if the matter of conflict resolution would be at least talked about, [...] If teenagers, when thought about having a romantic relationship, [...] heard about conflict resolution, they would have a different perspective. If a discussion starts, dialogue can enter, and not aggression or a more serious discussion. This situation would be better if we talked about how to solve problems, way before marriage. (Ind. 06)

[...] she didn't like I would rehearse, she'd say "you care more for your instruments than for me when you're playing" and this kind of stuff. I needed someone to be my partner. (Ind. 11)

[...] imagine your life dream is to raise your son, [...] because I never had my parents together, and my son did. When we broke up, it all ended, she was the cause. And now replacing me for some other guy is really tough. It was my dream to raise my son, I try not to think too much about it [...]. (Ind. 10)

In category 3) Repercussions of violence for the aggressor, the participants bring the burden of the complaint made by their partners. They construct the image of the object from these negative experiences and the repercussions of being accused of violence for their lives. The representation of this situation is expressed by the need of the estrangement of the partner and their child, by the risk of being arrested, and by material loss.

[...] the kids live with her. To tell the truth, after everything happened, I haven't seen my kids, it's been 2 months. I wanted to make it all right so I could get my kids and go out with them. [...]. (Ind. 3)
[...] If I disobey the restraining order by the court order I'll be arrested [...]. (Ind. 10)

[...] if she wants to leave, she better gets her stuff here. I'll stay with my stuff, everything I bought when I was single and my mom's furniture. [...] they called a police car and came home at dawn, the police came to pick up her things and I gave them everything, even the pans, I just kept what is mother's. (Ind. 09)

Category 4) The aggressor and his victimization, brings the social representations of the aggressor and his victimization before the denunciation of violence perpetrated against his current or former partner. It is possible to perceive both the construction of the image of the object and the knowledge about that object. The aggressors represent violence as if it were something external, belonging to the world, but what can happen to them and explain their desires to take revenge on the victim if something "more serious" occurs, a fact that would make their situation change.

The participants'speeches bring their representation on how they perceive violence against women in various perspectives. Initially, in relation to the Maria da Penha Law; then as something that happens to others, or in the attempt to continue or resume the relationship, even with the protective measure. And finally, the representation of violence and denunciation by men and the injustice experienced by them.

[...] Today, Maria da Penha Law unfortunately favors women, if they say anything then it is the true, the only true [...] if the woman gives a statement, she does not have to prove the man is guilty; it is the man who has to find a way to prove that he is innocent. I believe women act wrongly because of Maria da Penha Law, because they say and everyone believes them [...]. (Ind. 06)

[...] much violence against women is seen, but that's because they beat themselves. I saw this happening... the woman was hitting herself and called the police to tell them it was her husband. [...] I saw that [...] as it is a special women's police station, it abides by the rights of women, of course, the person was arrested [...] and was released on bail. [...] they [the police] should think more, investigate more, before arresting someone in flagrante. [...]. (Ind. 02)

[...] so, this is it: she reported me for threating her, things women say. She doesn't have any bruises, injuries, she just reports and said it was a threat. This is what happens, we don't have any defense [...]. Her son cannot know she is looking for me. So, it looks like I'm this dangerous guy, who hurts her. She would want distance from me and not look for me anymore, but it's not what she does [...] it is complicated... when she looks for me and something happens, the woman told me the judge has no mercy. [...]. (Ind. 07)

[...] every action has a reaction, it's not true when people say they can control everything that happens, because they can't. [...] this is why those men leave jail and kill women, because they don't think about the consequences [...]. When the guy is out of a situation, when they open his cell, his mind can only think about going after a woman if she owes him something. [...] he goes to jail against his will, maybe he'll be out in a few days and the woman is with another guy out there, it's a mistake. [...] (Ind. 12)

Men accused of violence against women feel wronged and victimized by their former partners, the system and the law, even 
when admitting what they did. There are complaints about the injustice, the rigor in relation to the act committed and the certainty that the acts committed should be avenged for having been accused of something that they did not do or did not do as described in the police report. There is an explanation they give that it is the woman's fault; the participant represents the male feelings as an announced behavior.

\section{DISCUSSION}

The profile of the aggressors and the main type of violence committed by them (moral), match the findings of an earlier study carried out in the same city ${ }^{(7)}$. On the other hand, a study carried out with the objective of investigating violence against women in Montes Claros City, state of Minas Gerais, found that the main type of violence practiced was physical (62.2\%), unlike the type of violence found in this study. However, when they checked the presence of a previous accusation, $25.8 \%$ of the participants had other reports for violence against women, similar to those of this study ${ }^{(12)}$.

In the participants' speeches, it is possible to see that they witnessed violent episodes of their father against their mother, proving the link between the suffered, the witnessed and the practice of violent acts, which corroborates with studies that show that the exposure to domestic violence in childhood is linked to the practice of violence later in adult life $\mathrm{e}^{(13-14)}$.

The fact that participants reaffirm that violence followed them during their lives, and that this may be a risk factor for their practice in adulthood, reinforces the fact that it can be considered as a condition transmissible throughout generations ${ }^{(13)}$.

As for the participants' representations about the conflicts and their resolution in the relationship with current or former partners, these men affirmed that the occurrence of conflicts is rare and unimportant. This position confirms a study that stresses that violence is practiced by men, against women, in exceptional circumstances and, generally, as a form of response or punishment to some behavior that they consider inappropriate by the woman ${ }^{(15)}$.

For them, the fact that women are entering in the labor market, having some economic autonomy and expanding their social circles leads to questioning their roles of maintainer and affirming that this is one of the reasons for conflicts to happen. This is because men like their partners to stay at home, taking care of their children and household activities, whether out of jealousy or other motives ${ }^{(16)}$.

This representation reaffirms the culturally and socially constructed gender roles in which men are the providers and women should be submissive and fulfill their duties at home and with their family. Therefore, when a woman "does not respect" this role, according to the opinion of these men, it is a reason for conflicts and possible situations of violence.

A study carried out in Rio Grande do Sul State analyzed, from the analytical category of gender, the dimension that violence against rural women has in the conception of health managers, workers and professionals. The authors identified in the women's statements that they are seen and treated only as mothers, wives, deprived of autonomy and providers of the well-being of the family and others. Some lines denote the difference of the socialization of women in relation to men, considered meek, submissive, living in the house (place permeated by conflicts and without formal laws), fact that allows implementing the law of the strongest, legitimizing the power of the husband on his wife and children ${ }^{(17)}$.

For conflict resolution, according to the men's perception of this study, there must be a dialogue between the couple. Lack of dialogue can lead to misunderstandings and even violence. In this sense, a study developed in Ecuador with 63 participants, analyzed the violence of couples from the perspective of the man, the woman and the professionals involved. The testimonies show that when men and women are only friends, trust is greater and they talk about everything; but when they become a couple problems arise, distrust comes, and the dialogue is gradually over, until it ends ${ }^{(16)}$.

Reflect about relationships, participate in group education methodologies and search for ways to maintain a harmonious coexistence based on the dialogue between men and women to reduce or resolve conflicts are ways to minimize/prevent the occurrence of violence ${ }^{(18-19)}$.

One of the reasons for the conflicts evidenced by the participants' reports was jealousy. This corroborates with other studies that present this feeling as a generative situation and as an intensifying factor of the conflicts in conjugal relations ${ }^{(12,16,19-20)}$.

Relationships are based on trust, and when it is broken, the relationship can change its configuration, moving from collaborative to competitive. Thus, when the couple does not break up, the possibility of further discussions and the occurrence of episodes of violence becomes more common ${ }^{(21)}$.

In addition to jealousy, ingratitude, sadness and revenge also appear as feelings experienced by participants. They believe that women are ungrateful because they do not recognize everything they have done right and proper in the relationship and seek to justify their actions because of this lack of recognition. This belief and justification are also described in a study conducted in Passo Fundo City, Rio Grande do Sul State, in which participants reported that their behavior was good, they were husbands dedicated to marriage, who never got involved in crimes, addictions and have always worked ${ }^{(22)}$.

After the act of violence and denunciation, there are consequences such as: the estrangement of the partner, the change in the coexistence with their children, the risk of being arrested and the loss of material goods. Concern for children is one of the most delicate points between fathers and mothers. Often, solving cases so that men who have practiced violence against women can see their children is very slow, as well as the request for reviewing the protective measure. However, despite the concern, when hostility persists, one blames the other for not fulfilling their obligations and, even worse, using their children to blackmail or pressure the other ${ }^{(23)}$.

Another consequence of the violence perceived in the reports is the loss of material goods. Problems related to the division of assets are implicit in this context. However, the dispute over these assets can sometimes be a trigger for conflicts and more violence against women ${ }^{(24)}$. 
In the last category, it is possible to perceive the representation that men have about the Maria da Penha Law. They say it should only be used in serious situations. This representation corroborates a study that sought to analyze the meanings that men accused of violence attribute to the aggressions perpetrated against women, in the context of the Maria da Penha Law and its public policies in Brazil. The study found that, for men, if women go to the police station it is unnecessary, since the case was mild and therefore could be solved at home ${ }^{(15)}$.

Even after violence, the speeches of men bring the attempt of coming closer to their partners. This circumstance reaffirms the description that the woman often shows understanding, justifies and minimizes the attitudes of her partner, as well as affirms that it was no her intention to denounce him because it was an isolated case and she would like to resume her relationship ${ }^{(23)}$.

Still in category 4 , it is possible to perceive the denial of the practice of violence and/or the justification of this by the men. This attitude was also noticed in the speeches of men accused of domestic violence, who have different visions about the circumstance for which they were accused, going through denial and concluding that the blame is on the woman ${ }^{(25)}$.

Women who denounce their partners for violence are often labeled as ill and reckless, listening to comments that demean them and lead them to believe that the marks of violence were caused by themselves ${ }^{(25)}$.

Other men understand violence as being only physical. Seen that, they claim that they did not commit any violence. This understanding that violence is only that which leaves marks denies the understanding of those who practiced the act as its authors or perpetrators. According to the hierarchy understood by them, their acts fall into the less serious category ${ }^{(15)}$.

\section{Study limitations}

As limitations of research regionality is mentioned, since the data collection took place in a single city. In addition, there was a wide age group of participants, who were adults aged 18 to 59 years old, which is justified by the prevalence of this pattern in other studies already performed.

Nevertheless, the limitations do not compromise the results and relevance of the presented topic. Studies with male perpetrators of violence are scarce and contribute to a new look the phenomenon of violence against women.

\section{Contributions to the Nursing and Health fields}

This study aims to contribute to the construction of a new perspective on the phenomenon of violence against women because it includes men who are the authors of this violence in the scientific productions and discussions of the subject. Within the scope of public policies, it may offer theoretical subsidy for including aggressors in strategies for coping with violence.

\section{FINAL CONSIDERATIONS}

In present research, the men intimated see conjugal violence as the fault of the victims and see themselves as victims of conflict situations. It is also noticed that the spread of violence comes since childhood. As for the consequences of the acts for which they were summoned, they fear arrest, and hold the representation that they are not guilty of the act of violence practiced or justify it as a reaction to an attitude presented by their partners.

The study development was of great importance because, from the collected data, the social representations that men summoned by conjugal violence have about the phenomenon were apprehended. This takes away, a little, the focus on the women who are victims of this violence, and are, in most of the time, the sources of information in studies on this subject. Hence, in working with men, it is possible to obtain the perspective of those who are the perpetrators of violence against their current and former partners.

Considering that, it of utmost importance that further research is developed with this population to understand the facts and factors that lead to the situation of violence. Strategies for reducing and even eradicating violence against women should be developed, given many victims remain with their aggressors, as well as many perpetrators of violence after breaking up with a woman, maintain the same habits and behavior of violence in the new relationship.

Therefore, including men who are the authors of the actions is as a vital pillar for facing violence against women. Initiatives should be promoted with the aim of changing the social and gender relations and violent behaviors used to solve domestic conflicts.

\section{FUNDING}

The research was funded by a PhD grant awarded by the Araucária Foundation, Agreement n³60/14.

\section{REFERENCES}

1. World Health Organization. Global and regional estimates of violence against women: prevalence and health effects of intimate partner violence and non-partner sexual violence. Geneva: World Health Organization; 2013.

2. Fernández MD, Silva IMM, Vázquez-Portomeñe F, Calvo MSR. Features and consequences of gender violence: Study of cases confirmed by a conviction. Rev Esp Med Legal [Internet]. 2017 [cited 2018 Nov 19];43(3) :115-122. Available from: https://doi.org/10.1016/j. remle.2017.07.003

3. Waiselfisz JJ. Mapa Da Violência 2015: homicídios de mulheres no Brasil. Brasília: FLACSO, 2015.

4. Soares JSF, Lopes MJM. Experiences of women in situation of violence seeking care in the health sector and in the intersectoral network. Interface [Internet]. 2018 [cited 2018 Nov 19];22(66):789-800. Available from: http://dx.doi.org/10.1590/1807-57622016.0835

5. Barufaldi LA, Souto RMCV, Correia RSB, Montenegro MMS, Pinto IV, Silva MMA, et al. Gender violence: a comparison of mortality from 
aggression against women who have and have not previously reported violence. Ciênc Saúde Colet [Internet]. 2017 [cited 2018 Aug 25];22(9):2929-38. Available from: http://dx.doi.org/10.1590/1413-81232017229.12712017

6. Meneghel SN, Margarites AF. Femicide in Porto Alegre, Rio Grande do Sul State, Brazil: gender iniquities in dying. Cad Saúde Pública[Internet]. 2017 [cited 2018 Aug 25];33(12):1-11. Available from: http://www.scielo.br/pdf/csp/v33n12/1678-4464-csp-3312-e00168516.pdf

7. Madureira AB, Raimondo ML, Ferraz MIR, Marcovicz GV, Labronici LM, Mantovani MF. Profile of men who commit violence against women who are arrested in delicto flagrante: contributions to confronting the phenomenon. Esc Anna Nery[Internet]. 2014 [cited 2018 Aug 25];18(4):600-6. Available from: http://www.gnresearch.org/doi/10.5935/1414-8145.20140085

8. Ribeiro LP, Antunes-Rocha MI. Social representation theory: history, approaches, methods and perspectives. Psicol Soc[Internet]. 2016 [cited 2018 Nov 19];28(2): 407-9. Available from: http://dx.doi.org/10.1590/1807-03102016v28n2p407

9. Moscovici S. A psicanálise, sua imagem e seu público. Petrópolis: vozes; 2012.

10. Tong A, Sainsbury P, Craig J. Consolidated criteria for reporting qualitative research (COREQ): a 32- item checklist for interviews and focus group. Int J Qual Heal Care[Internet]. 2007 [cited 2018 Jul 28];19(6):349-57. Available from: https://doi.org/10.1093/intqhc/mzm042

11. Minayo MCS. O Desafio da Pesquisa Social. In: Minayo MCS, Deslande SSF, Gomes R. Pesquisa Social: teoria, método e criatividade. Rio de Janeiro: Vozes, 2012.

12. Romagnoli R. [Violence Against Women In Montes Claros]. Barbarói [Internet]. 2015 [cited 2018 Aug 25];1(43):27-47. Available from: https:// online.unisc.br/seer/index.php/barbaroi/article/view/4815/4407 Portuguese.

13. Fleming PJ, McCleary-Sills J, Morton M, Levtov R, Heilman B, Barker G. Risk factors for men's lifetime perpetration of physical violence against intimate partners: results from the international men and gender equality Survey (IMAGES) in eight countries. PLoS One [Internet]. 2015 [cited 2018 Aug 25];10(3):1-18. Available from: https://doi.org/10.1371/journal.pone.0118639

14. FRA-Agência dos Direitos Fundamentais da União Europeia. Violência contra as mulheres: um inquérito à escala da União Europeia Síntese dos resultados. Luxemburgo: Serviço das Publicações da União Europeia, 2014.

15. Moraes AF, Ribeiro L. State policy on violence against women in Brazil and men's accountability. Sex Salud Soc[Internet]. 2012 [cited 2018 Sep 19];(11):37-58. Available from: http://www.scielo.br/pdf/sess/n11/a03n11.pdf

16. Boira S, Carbajosa P, Méndez R. Fear, conformity and silence. Intimate partner violence in rural areas of Ecuador. Psychosoc Interv[Internet] 2016 [cited 2018 Sep 15];25(1):9-17. Available from: http://dx.doi.org/10.1016/j.psi.2016.10.001

17. Costa MC, Lopes MJM, Soares JSF. Violence against rural women: gender and health actions. Esc Anna Nery[Internet]. 2015 [cited 2018 Sep 15];19(1):162-8. Available from: http://www.gnresearch.org/doi/10.5935/1414-8145.20150022

18. Taylor AY, Moura T, Scabio JL, Borde E, Afonso JS, Barker G. Isso aqui não é vida para você: masculinidades e não violência no Rio de Janeiro, Brasil. Resultados do Estudo Internacional sobre Homens e Igualdade de Gênero (IMAGES) com foco na violência urbana. Washington, DC e Rio de Janeiro: Promundo; 2016.

19. Paixão GPN, Gomes NP, Diniz NMF, Couto TM, Vianna LAC, Santos SMP, et al. Situations which precipitate conflicts in the conjugal relationship: the women's discourse. Texto Contexto Enferm [Internet]. 2014 [cited 2018 Sep 19];23(4):1041-9. Available from: http://www. scielo.br/pdf/tce/v23n4/0104-0707-tce-23-04-01041.pdf

20. Patrício JA. [Violence against women: processes and contexts of victimization]. Forum Sociológico. [Internet]. 2014 [cited 2018 Sep 19];(25):33-43. Available from: http://journals.openedition.org/sociologico/902 Portuguese.

21. Pereira R. Por Why don't you just break up? the loss of confidence in marriage. Pensando Fam[Internet]. 2015 [cited 2018 Sep 19];19(2):3-20. Available from: http://pepsic.bvsalud.org/scielo.php?script=sci_arttext\&pid=S1679-494X2015000200002\&lng=pt\&nrm=iso\&tlng=pt

22. Oliveira LRF, Bressan C. The perception of the person who killed for love. Mudanças-Psicol da Saúde. [Internet]. 2014 [cited 2018 Aug 15];22(1):1-10. Available from: http://dx.doi.org/10.15603/2176-1019/mud.v22n1p21-30

23. Boira S, Carbajosa P, Marcuello C. Partner violence from three perspectives: Victims, abusers, and professionals. Psychosoc Interv[Internet]. 2013 [cited 2018 Aug 15];22(2):125-33. Available from: http://dx.doi.org/10.5093/in2013a15

24. Acosta DF, Gomes VLO, Fonseca AD, Gomes GC. Violence against women commited by intimate partners: (in)visibility of the problem. Texto Contexto Enferm [Internet]. 2015 [cited 2018 Sep 19];24(1):121-7. Available from: http://www.scielo.br/pdf/tce/v24n1/0104-0707tce-24-01-00121.pdf

25. Silva ACLG, Coelho EBS, Njaine K. [Conjugal violence: controversies in the reports of intimate partners in police investigations]. Ciênc Saúde Coletiva [Internet]. 2014 [cited 2018 Sep 19];19(4):1255-62. Available from: http://www.scielo.br/pdf/csc/v19n4/1413-8123csc-19-04-01255.pdf Portuguese. 